\title{
Potensi Scopoletin sebagai Agonis Reseptor Transferin 2 untuk Pengembangan Terapi Anemia Defisiensi Besi
}

\author{
Asti Swari Paramanindita ${ }^{1}$, Dono Indarto ${ }^{2}$, Balgis $^{3}$ \\ 1. Program Studi Kedokteran, Fakultas Kedokteran, Universitas Sebelas Maret, Surakarta \\ 2. Bagian Fisiologi, Fakultas Kedokteran, Universitas Sebelas Maret, Surakarta \\ 3. Bagian Ilmu Kesehatan Masyarakat, Universitas Sebelas Maret, Surakarta
}

Korespondensi : donoIND323@gmail.com

\begin{abstract}
ABSTRAK
Pendahuluan: Anemia Defisiensi Besi (ADB) dapat disebabkan oleh ketidakseimbangan antara asupan dan kehilangan besi dalam sirkulasi. Peningkatan sekresi hepsidin berperan penting dalam etiologi ADB. Ekspresi protein hepsidin dapat terjadi melalui tiga jalur, salah satunya melalui peningkatan interaksi antara holo Transferin (holo-Tf) dengan Reseptor Transferin 2 (RTf-2). Hingga saat ini belum ada senyawa eksogen yang dapat mengaktifkan RTf-2. Tanaman herbal Indonesia banyak dimanfaatkan sebagai tanaman obat tetapi belum ada yang digunakan untuk terapi ADB. Tujuan penelitian ini adalah untuk mengeksplorasi senyawa fitokimia dalam tanaman herbal Indonesia yang dapat berperan sebagai agonis RTf-2.

Metode: Penelitian ini adalah penelitian bioinformatika dengan metode molecular docking. Piranti lunak SWISS-MODEL digunakan untuk pemodelan RTf-2 karena struktur protein RTf-2 belum diketahui. Standar holo-Tf didapatkan dari laman Protein Data Bank dengan kode akses PDB ID 1SUV. Sampel penelitian adalah senyawa fitokimia yang memenuhi kriteria (1) terdaftar dalam basis data HerbalDB (2) memiliki struktur tiga dimensi pada laman PubChem (3) memenuhi kriteria Lipinski's Rule of Five. Piranti lunak AutoDock Vina 1.1.2 digunakan untuk menganalisis energi ikatan dengan satuan kkal/mol. Interaksi ikatan antara sampel dengan RTf-2 divisualisasi menggunakan piranti lunak Chimera 1.10rc dan atau Pymol 1.7.

Hasil: Skor docking dari interaksi modifikasi holo-Tf dengan RTf-2 adalah $-6,4 \pm 0,1$ $\mathrm{kkal} / \mathrm{mol}$ pada Arg466 dan $-3,4 \pm 0,1 \mathrm{kkal} / \mathrm{mol}$ pada Arg689. Hasil visualisasi standar menunjukkan Tf tidak hanya berinteraksi dengan kedua residu tersebut tetapi juga pada Asp642 dan Ile682. Scopoletin memiliki skor docking sebesar $-7,1 \pm 0,1 \mathrm{kkal} / \mathrm{mol}$ pada Arg466 dan -5,4 $\pm 0,1 \mathrm{kkal} / \mathrm{mol}$ pada Arg689. Scopoletin dapat berinteraksi dengan RTf-2 pada residu Arg466, Arg689, dan Leu630.

Kesimpulan: Scopoletin kemungkinan besar bersifat sebagai agonis RTf-2 secara komputasi. Uji in vitro sebaiknya dilakukan untuk membuktikan efek agonis scopoletin pada RTf-2.
\end{abstract}

Kata Kunci: Anemia Defisiensi Besi, Fitokimia, Scopoletin, Molecular Docking, RTf-2 


\begin{abstract}
Introduction: Iron Deficiency Anemia (IDA) is caused by imbalance between iron intake and iron loss in blood circulation. Increased hepcidin level plays an important role in the etiology of IDA. Normally, expression of hepcidin protein is controlled by three different pathways, one of them is interaction between holo Transferin (Holo-Tf) and Transferrin Receptor 2 (TfR-2). Recently, Indonesian herbal plants have widely been used as herbal medicine but there is no active compound that can activate TfR-2 for IDA therapy. The aim of this study was to explore phytochemicals derived from Indonesian herbal plants to interact with TfR-2.

Methods: The study was a bioinformatics study with a molecular docking method. The SWISS-MODEL software was used to make TfR-2 protein modeling because the molecular structure of TfR-2 remains unknown. Holo-Tf was used as a standard ligand and obtained from Protein Data Bank with PDB ID 1SUV. All Indonesian phytochemicals which (1) registered at HerbalDB (2) had a three-dimensional molecular structure at PubChem (3) met Lipinski's Rule of Five criteria were used in this study. AutoDock Vina 1.1.2 was used to analyze the binding affinity which was in $\mathrm{kcal} / \mathrm{mol}$. Phytochemical-TfR-2 binding complexes were visualized by using Chimera 1.10rc and or Pymol 1.7.

Result: The docking scores of holo-Tf modification with TfR-2 were $-6,4 \pm 0,1 \mathrm{kcal} / \mathrm{mol}$ at Arg466 and $-3,4 \pm 0,1 \mathrm{kcal} / \mathrm{mol}$ at Arg689 respectively. Interaction of modification holo-Tf and TfR-2 was observed not only at Arg466 and Arg689 but also with Asp642 and Ile682. Docking scores of scopoletin were $-7,1 \pm 0,1 \mathrm{kcal} / \mathrm{mol}$ at Arg466 and $-5,4 \pm 0,1$ $\mathrm{kcal} / \mathrm{mol}$ at Arg689. Scopoletin could interact with TfR-2 at Arg466, Arg689, and Leu630 residues.
\end{abstract}

Conclusions: Computationally, scopoletin is a potential TfR-2 agonist. In future studies, in vitro assay will be used to evaluate the agonist effect of scopoletin in TfR-2.

Keywords: Iron Deficiency Anemia, Phytochemical, Scopoletin, Molecular Docking, TfR-2

\section{PENDAHULUAN}

ADB merupakan salah satu gangguan anemia karena ketidakseimbangan antara asupan dan kehilangan besi dalam tubuh ${ }^{1}$. Suplementasi besi oral merupakan terapi lini pertama pada pasien ADB karena terapi ini murah, aman, dan efektif dalam meningkatkan besi dalam tubuh ${ }^{2}$. Walaupun secara umum suplementasi besi oral efektif untuk mengatasi ADB, beberapa pasien ADB tidak menunjukkan respon terhadap terapi tersebut ${ }^{1}$. Salah satu penyebab yang telah diketahui adalah akibat peningkatan hormon hepsidin.

Semakin tinggi level hepsidin dalam tubuh maka akan menghambat proses absorbsi besi usus, menghambat pelepasan besi daur ulang dari makrofag limpa, dan menghambat proses pelepasan cadangan besi dari hepar ${ }^{3}$. Peningkatan ini dapat disebabkan oleh mutasi enzim matriptase 2 (MT2) yang bekerja pada jalur Bone Morphogenetic Protein (BMP) serta gangguan pada jalur IL- 6 dan Reseptor Transferin 2 (RTf-2) ${ }^{4}$. Jalur IL6 distimulasi oleh adanya inflamasi maupun infeksi sedangkan stimulasi jalur RTf- 2 belum banyak diketahui penyebabnya ${ }^{5}$. Hal ini dikarenakan struktur dan penelitian dari protein RTf- 2 belum banyak dilakukan sehingga peran pasti RTf- 2 dalam menyebabkan tingginya kadar hepsidin dalam kasus anemia masih belum diketahui.

Senyawa aktivator jalur RTf-2 hingga saat ini masih belum diketahui, 
kecuali holo-Tf. Belum ada penelitian yang menerangkan pemicu keluarnya hepsidin melalui jalur ini sehingga pengembangan obat untuk menghambat reseptor ini masih dalam batas degradasi mRNA. Bila agonis sudah ditemukan maka dapat dikembangkan untuk terapi pasien ADB yang tidak responsif besi oral akibat gangguan hepsidin jalur RTf-2.

Keanekaragaman hayati Indonesia mendorong pengembangan herbal sebagai obat dalam menanggulangi berbagai penyakit termasuk $\mathrm{ADB}^{6}$. Fitokimia dari berbagai tanaman obat di Indonesia dapat dimanfaatkan untuk mengetahui senyawa apakah yang dapat mengaktifkan RTf-2 dan membantu melepaskan sekresi hepsidin.

Proyek pengembangan obat baru umumnya membutuhkan waktu lama dan biaya besar $^{7}$. Salah satu cara mengatasi kendala tersebut adalah dengan virtual screening (VS). VS atau penapisan virtual adalah salah satu strategi dalam mendesain molekul obat baru menggunakan kimia komputasi dimana salah satu metode yang digunakan adalah dengan molecular docking. Molecular docking dapat memprediksi senyawa yang memiliki aktivitas biologis dan dapat digunakan untuk menuntun penemuan senyawa obat secara komputasional ${ }^{8}$. Piranti lunak molecular docking telah banyak digunakan untuk mencari interaksi antara ligan dengan reseptor. Salah satu piranti lunak yang digunakan dalam penelitian ini adalah AutoDock Vina.

Penelitian ini merupakan tahap awal untuk pengembangan obat ADB. Penelitian bertujuan mencari senyawa aktivator jalur RTf-2 selain holo-Tf sehingga dapat digunakan untuk pengembangan terapi ADB terkait gangguan hepsidin.

\section{SUBJEK DAN METODE}

Penelitian berupa penelitian observasional bioinformatika dengan menggunakan metode molecular docking yang dilaksanakan di Laboratorium Fisiologi FK UNS. Penelitian ini menggunakan struktur tiga dimensi dari sampel senyawa fitokimia, senyawa standar holo-Tf, dan protein RTf-2. Sampel penelitian merupakan struktur tiga dimensi dari fitokimia tanaman herbal Indonesia yang terdaftar pada basis data HerbalDB, memiliki struktur tiga dimensi pada laman PubChem, dan memenuhi kriteria Lipinski's Rule of Five yaitu: 1) berat molekul $<500 \mathrm{~g} / \mathrm{mol}$; 2) koefisien logaritmik untuk perbandingan oktanol dan air pada senyawa $(\log P)<5 ; 3)$ ikatan hidrogen donor <5; 4) ikatan hidrogen akseptor $<10^{9}$.

Hardware yang digunakan adalah HP 1000 Notebook PC dengan processor Intel ${ }^{\circledR}$ Core TM i3-3110M CPU @2.40GHz (4CPUs) dan sistem operasi Windows 7 Ultimate Edition. Piranti lunak yang digunakan adalah AutoDock Vina 1.1.2 dalam piranti lunak PyRx, AutoDock Tools, SWISS-MODEL, Chimera 1.10rc, dan Pymol 1.7.

Struktur protein RTf-2 hingga saat ini belum tersedia. Oleh karena itu, proses homology modeling RTf-2 perlu dilakukan untuk mendapatkan struktur tiga dimensinya. Molekul protein RTf-2 manusia diunduh dalam format FASTA melalui laman http://www.ncbi.nlm.nih.gov/ protein/AAI42631.1. FASTA RTf-2 tersebut kemudian dibentuk pemodelan struktur tiga dimensi dari protein terdekat dengan 
sequence identity tertinggi melalui SWISSMODEL (www.swissmodel.expasy.org). Setelah diperoleh struktur tiga dimensinya, model RTf-2 dilakukan optimasi dengan menghilangkan molekul air dan menambahkan atom hidrogen polar dengan AutoDock Tools. Proses molecular docking dilakukan terhadap senyawa holo-Tf dan 422 senyawa fitokimia.

Proses molecular docking dilakukan pada dua posisi grid box agar proses docking terbatas di daerah sekitar tempat ikatan Tf di RTF-2. Grid box ditentukan menggunakan AutoDock Tools yang difokuskan pada tempat ikatan $\mathrm{Tf}$ terhadap RTf-2, yaitu Arg466 dan Arg689.(10) Dua grid box tersebut adalah $X$ center $= \pm 105,5405 ; Y$ center $=$ $\pm-2,3084 ; Z$ center $= \pm-16,6709$ (Arg466) dan $X$ center $= \pm 129,600$; $Y$ center $= \pm 9,523 ; Z$ center $= \pm-17,871$ (Arg689).

Proses molecular docking menggunakan piranti lunak AutoDock Vina 1.1.2. Hasil molecular docking senyawa holo-Tf pada RTf-2 dijadikan standar untuk hasil docking senyawa fitokimia. Struktur tiga dimensi Tf diperoleh dari komplek Tf-RTf-1 (PDB ID 1SUV) yang diunduh melalui Protein Data Bank (www.rcsb.org). Komplek TfRTf-1 kemudian dipisahkan melalui piranti lunak AutoDock Tools. Molekul Tf adalah molekul berukuran besar sehingga untuk melakukan proses molecular docking antara Tf dan RTf-2 menggunakan program AutoDock Vina perlu dilakukan modifikasi molekul Tf. Modifikasi berupa pemotongan asam amino Tf yang memiliki interaksi dengan RTf-2 sesuai penelitian Yamamura dan
Sakajiri ${ }^{10}$, yaitu pada Glu56 dan Glu328. Pemotongan residu menggunakan piranti lunak AutoDock Tools. Proses pemotongan mempertimbangkan bentuk tiga dimensi dari hasil potongan. Peneliti melakukan pemotongan $\mathrm{Tf}$ menjadi dua bagian, yaitu pada Tf Arg50- Glu56 (bagian I) serta Tf Lys144-Lys148 dan Glu328 (bagian II).

Potongan Tf tersebut kemudian dilakukan validasi molecular docking pada tempat ikatannya di RTf-2. Glu56 (bagian I) di docking-kan pada Arg466 dan Glu328 (bagian II) di docking-kan pada Arg689. Proses molecular docking dilakukan sebanyak tiga kali untuk mengambil skor docking rata- rata dengan rmsd (root mean square deviation) $<2 \AA$ agar skor dan konformasi yang digunakan dianggap valid serta tidak memiliki perbedaan yang bermakna ${ }^{8}$. Skor docking yang diperoleh dijadikan standar untuk menentukan aktivitas senyawa fitokimia.

Proses molecular docking senyawa fitokimia akan menghasilkan skor docking dan konformasi ikatan. Senyawa fitokimia dianggap sebagai agonis RTf-2 bila memiliki skor docking $\leq$ skor docking potongan Tf di Arg466 dan Arg689 serta memiliki interaksi ikatan pada kedua tempat ikatan tersebut. Interaksi ikatan dapat dilihat dengan visualisasi menggunakan Chimera 1.10rc atau Pymol 1.7 .

Analisis molecular docking dilakukan dengan membandingkan skor docking berupa energi ikatan (kkal/mol) dan interaksi ikatan antara hasil docking standar dengan senyawa fitokimia. 


\section{HASIL}

Pemodelan struktur tiga dimensi RTf-2 menghasilkan model yang memilki sequence identity sebesar 48,19\%. Protein cetakan (protein template) yang digunakan adalah komplek protein Tf- RTf-1 manusia (PDB ID 3S9L).

Validasi molecular docking potongan $\mathrm{Tf}$ dengan RTf-2 dilakukan masing- masing sebanyak tiga kali pada dua tempat ikatan. Hasil validasi potongan Tf dengan RTf-2 memiliki skor docking rerata sebesar $-6,4 \pm 0,1 \mathrm{kkal} / \mathrm{mol}$ (Glu56Arg466) dan -3,4 $\pm 0,1 \mathrm{kkal} / \mathrm{mol}$ (Glu328Arg689) dengan rmsd 0,0 (Tabel 1). Hasil docking potongan $\mathrm{Tf}$ kemudian dilakukan visualisasi untuk melihat interaksi ikatan yang terbentuk. Pada Gambar 1 terlihat potongan Tf membentuk interaksi ikatan pada Glu56 (Tf) dengan Arg466 (RTf-2) serta pada Glu328 (Tf) dengan Asp642, Ile682, Arg689 (RTf-2).

Tabel 1. Skor docking potongan Tf pada RTf-2

\begin{tabular}{lcc}
\hline Interaksi & $\begin{array}{c}\text { Skor } \\
\text { docking }\end{array}$ & $\begin{array}{c}\text { Skor docking } \\
\text { rerata } \\
\text { (kkal/mol) } \pm\end{array}$ \\
& & $\begin{array}{c}\text { Standar Deviasi } \\
(\mathrm{k} \text { ( }) \text { ( ) }\end{array}$ \\
\hline Glu56- & $-6,3$ & \\
Arg466 & $-6,4$ & $-6,4 \pm 0,1$ \\
\hline Glu 328- & $-6,4$ & \\
Arg689 & $-3,5$ & \\
\hline
\end{tabular}

Selanjutnya dilakukan molecular docking ke-422 senyawa fitokimia pada dua daerah tempat ikatan Tf, yaitu Arg466 dan Arg689. Proses molecular docking diulang sebanyak tiga kali untuk mengambil nilai rerata. Dari hasil docking didapatkan scopoletin memiliki skor docking rerata sebesar $-7,1 \pm 0,1$ pada

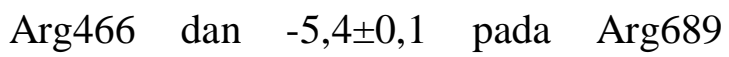
(Tabel 2). Hasil molecular docking scopoletin pada daerah Arg466 memperlihatkan adanya interaksi ikatan hidrogen di Arg466, Leu630 sedangkan pada daerah Arg689 memperlihatkan adanya interaksi ikatan hidrogen di Arg689 (Gambar 1).

Tabel 2. Skor docking scopoletin pada RTf-2

\begin{tabular}{|c|c|c|c|}
\hline $\begin{array}{c}\text { Kode } \\
\text { PubChem }\end{array}$ & $\begin{array}{c}\text { Interaksi } \\
\text { fitokimia- } \\
\text { RTf-2 }\end{array}$ & $\begin{array}{c}\text { Skor } \\
\text { docking }\end{array}$ & $\begin{array}{c}\text { Skor } \\
\text { docking } \\
\text { rerata } \\
(\mathrm{kkal} / \mathrm{mol}) \\
\pm \mathrm{SD}\end{array}$ \\
\hline \multirow{2}{*}{5280460} & $\begin{array}{l}\text { Scopoletin- } \\
\text { Arg466 }\end{array}$ & $\begin{array}{l}-7,1 \\
-7,0 \\
-7,1\end{array}$ & $-7,1 \pm 0,1$ \\
\hline & $\begin{array}{c}\text { Scopoletin- } \\
\text { Arg689 }\end{array}$ & $\begin{array}{l}-5,3 \\
-5,4 \\
-5,5 \\
\end{array}$ & $-5,4 \pm 0,1$ \\
\hline
\end{tabular}

\section{PEMBAHASAN}

Struktur protein RTf-2 hingga saat ini belum diketahui. Peneliti menggunakan model RTf-2 yang dibentuk dari kompleks Tf-RTf-1 manusia untuk melakukan proses molecular docking. Model RTf-2 yang didapat memiliki sequence identity sebesar 48,19\%. Model yang dihasilkan dianggap dapat mewakili struktur tiga dimensi dari RTf-2 karena memenuhi kriteria rule of thumb dari homology modeling, yaitu sequence protein target yang memiliki residu melebihi 100 dianggap identik dengan struktur protein template bila memiliki sequence identity minimal sebesar $25 \%^{11}$. 

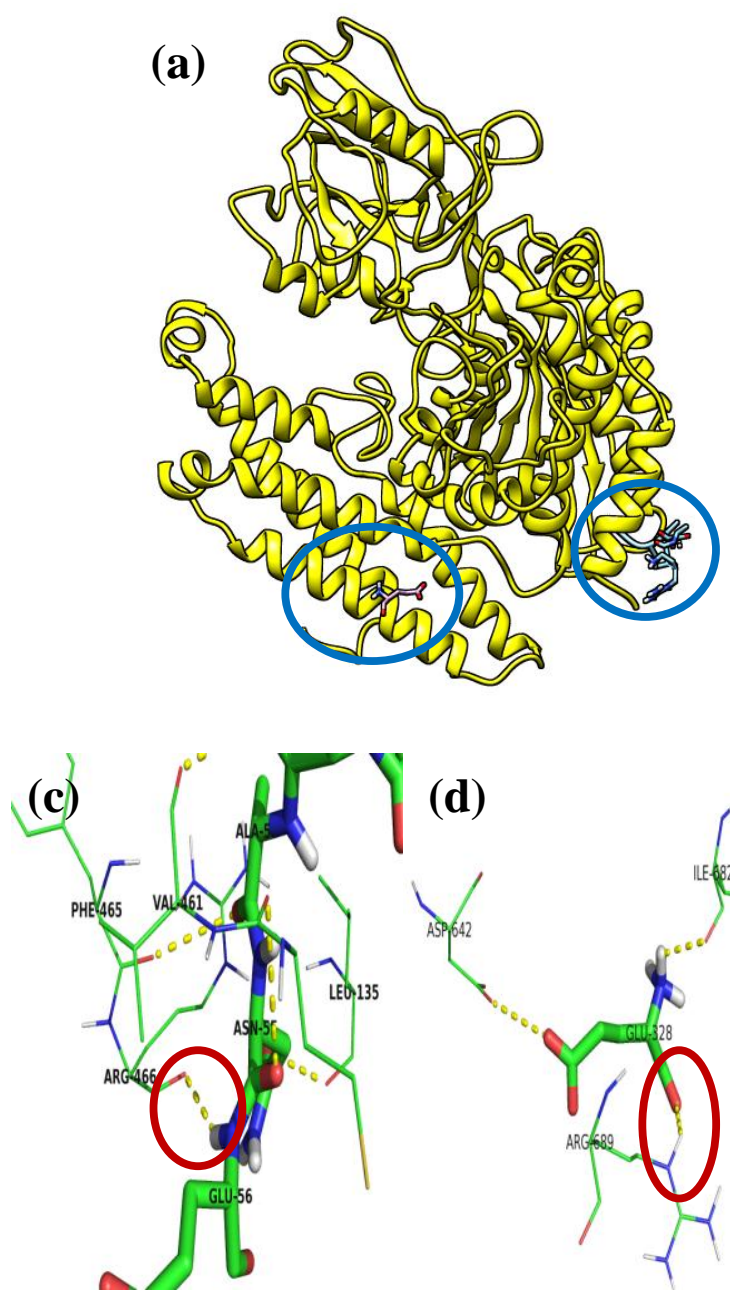

(d)

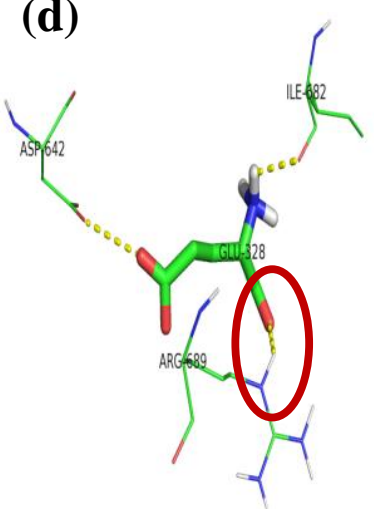

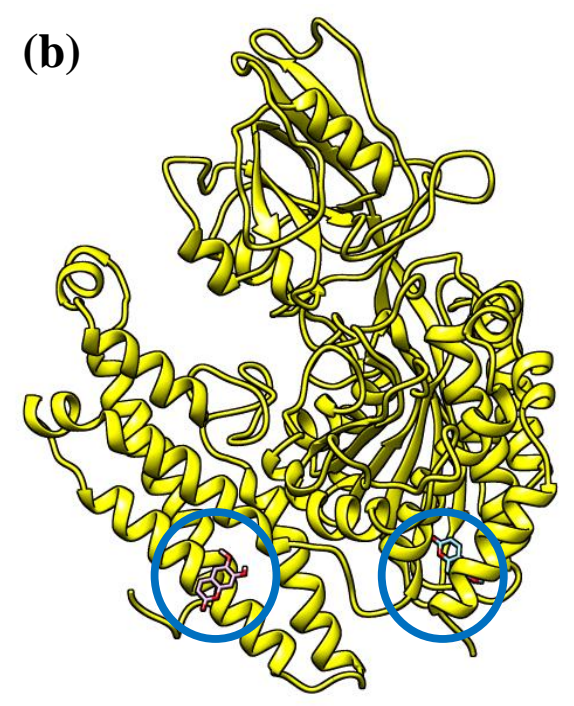

(e)

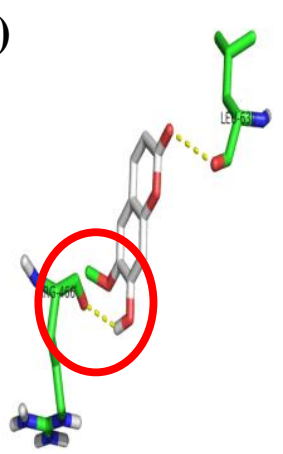

(f)

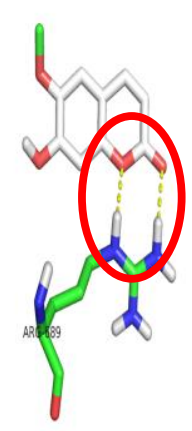

Gambar 1. Visualisasi hasil molecular docking potongan Tf dan scopoletin pada RTf-2.

(a) Visualisasi posisi potongan Tf pada RTf-2 dengan Chimera 1.10rc. Posisi potongan Tf ditunjukkan dengan lingkaran biru; (b) Visualisasi posisi scopoletin pada RTf-2 dengan Chimera 1.10rc. Posisi scopoletin ditunjukkan dengan lingkaran biru; (c)Interaksi ikatan antara Glu56(Tf)Arg466(RTf-2) yang ditunjukkan oleh lingkaran merah; (d)Interaksi ikatan antara Glu328(Tf)Arg689(RTf-2) yang ditunjukkan oleh lingkaran merah; (e)Interaksi ikatan antara scopoletinArg466(RTf-2) yang ditunjukkan lingkaran merah; (f)Interaksi ikatan antara scopoletinArg689(RTf-2) yang ditunjukkan lingkaran merah. Hijau: atom Karbon (C), merah: atom Oksigen $(O)$, putih: atom Hidrogen $(H)$, biru: atom Nitrogen $(N)$, garis putus-putus kuning: interaksi antaratom. 
Proses molecular docking antara potongan Tf dengan model RTf-2 menghasilkan dua skor docking rerata, yaitu pada Glu56-

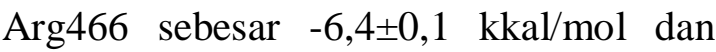
pada Glu328-Arg689 sebesar $-3,4 \pm 0,1$ $\mathrm{kkal} / \mathrm{mol}$. Kemudian hasil visualisasi memperlihatkan adanya interaksi antara Glu56 dengan Arg466 dan Glu328 dengan Arg689, Asp642, Ile682 (Gambar 1). Interaksi ikatan antar asam amino dipengaruhi oleh sifat dari asam amino terkait. Interaksi ikatan yang terbentuk antara Glu56 dengan Arg466 dan Glu328 dengan Arg689 adalah interaksi ikatan ionik karena sifat asam amino Glutamat bermuatan negatif sedangkan asam amino Arginin bermuatan positif sehingga terdapat gaya tarik menarik diantara keduanya $^{12}$. Ikatan ionik terbentuk melalui transfer satu atau lebih elektron valensi dari satu atom ke atom lainnya untuk membentuk ikatan kimia yang stabil ${ }^{12,13}$.

Hasil molecular docking scopoletin terhadap RTf-2 mendapatkan hasil skor docking yang lebih rendah daripada potongan $\mathrm{Tf}$, yaitu $-7,1 \pm 0,1$ $\mathrm{kkal} / \mathrm{mol}$ pada Arg466 dan $-5.4 \pm 0,1$ kkal/mol pada Arg689. Semakin rendah skor docking maka tingkat kestabilan antara ligan dan reseptor semakin baik sehingga akan terbentuk ikatan yang lebih kuat $^{14}$. Semakin negatif hasil skor docking maka energi yang dibutuhkan oleh scopoletin untuk membentuk ikatan dengan RTf-2 juga lebih kecil dibandingkan energi yang dibutuhkan $\mathrm{Tf}$ untuk berikatan dengan RTf-2.

$\begin{array}{ll}\text { Hasil visualisasi scopoletin } \\ \text { menunjukkan } & \text { terbentuknya ikatan } \\ \text { hidrogen pada Arg466, Leu630 dan }\end{array}$ Arg689 (Gambar 1). Ikatan hidrogen merupakan salah satu gaya tarik menarik antarmolekul. Ikatan hidrogen terbentuk antara atom yang bersifat elektronegatif (atom yang cenderung menerima elektron) dengan atom hidrogen yang terikat pada atom lain yang juga bersifat elektronegatif ${ }^{13}$.

Jenis interaksi senyawa scopoletin dengan residu RTf-2 yang diperoleh dari hasil molecular docking berbeda dengan jenis interaksi pada potongan Tf yang dijadikan standar. Perbedaan jenis ikatan antara $\mathrm{Tf}$ dengan senyawa fitokimia pada Arg466 dan Arg689 disebabkan oleh senyawa standar yang digunakan adalah protein, yaitu Tf. Pada interaksi proteinprotein, interaksi yang terjadi merupakan interaksi antara residu dengan residu. Interaksi yang terbentuk pada senyawa standar adalah antara residu Glutamat yang bermuatan negatif dengan Arginin yang bermuatan positif sehingga terjadi perbedaan muatan dan terbentuk ikatan ionik $^{12}$. Sedangkan pada interaksi liganprotein, interaksi yang terbentuk merupakan interaksi antarmolekul yang berdekatan, yaitu antara atom dari residu protein dengan atom dari ligan ${ }^{12,13}$. Interaksi yang terjadi pada liganprotein memperhatikan atom yang terlibat dimana pada visualisasi hasil docking scopoletin memperlihatkan keterlibatan atom hidrogen (Gambar 1). Ikatan hidrogen yang terbentuk merupakan ikatan antarmolekul yang lemah sehingga senyawa fitokimia diprediksi memiliki interaksi yang reversibel dengan RTf- $2^{12}$.

Penggunaan kriteria Lipinski's Rule of Five bertujuan untuk mendapatkan senyawa aktif yang mudah diabsorbsi tubuh $^{9}$. Penapisan kandidat senyawa obat menggunakan kriteria ini diharapkan bisa memperoleh senyawa yang memiliki 
bioavailabilitas tinggi di dalam tubuh manusia. Aturan Lipinski dapat menentukan karakter hidrofobik atau hidrofilik suatu senyawa untuk berdifusi secara pasif melewati membran sel $^{15}$. Scopoletin memiliki berat mokeul sebesar 192, $16812 \mathrm{~g} / \mathrm{mol}$; nilai Log P sebesar 1,5; satu donor ikatan hidrogen dan empat akseptor ikatan hidrogen. Karakterstik scopoletin yang memenuhi aturan Lipinski menunjukkan scopoletin dapat dengan mudah menembus membran sel saluran cerna dan masuk ke dalam sirkulasi tubuh manusia.

Scopoletin merupakan senyawa golongan fenilpropanoid derivat kumarin. Beberapa tanaman yang mengandung scopoletin adalah Imperata cylindrica (alang- alang), Aglaia edulis, Chrysanthemum leucanthemum (bunga daisy), Citrus sinensis (jeruk manis), Curcuma mangga (temu mangga/kunir putih), Hedyotis capitellata, Morinda citrifolia (mengkudu), Schleichera oleosa (kesambi), Urtica dioica (jelatang), Urtica urens. Scopoletin pada buah mengkudu memiliki efek menurunkan tekanan darah dan merelaksasikan otot polos ${ }^{16}$. Penelitian lain menyatakan bahwa scopoletin memiliki efek menghambat proliferasi sel kanker prostat dengan menginduksi apoptosis ${ }^{17}$. Scopoletin juga memiliki efek antioksidan, hepatoprotektif, antiinflamasi, antialergi, dan antiangiogenesis ${ }^{18,19,20}$.

Penelitian yang dilakukan oleh peneliti merupakan jenis penelitian biokomputasi dengan menggunakan sumber data dari database internet. Penelitian ini memiliki keterbatasan. Pertama, protein dan senyawa standar holo-Tf yang digunakan adalah hasil modifikasi sehingga mungkin mempengaruhi hasil docking. Kedua, piranti lunak molecular docking yang digunakan adalah AutoDock Vina dimana pada program ini makromolekul (protein/reseptor) dianggap memiliki bentuk rigid/kaku sedangkan ligan berbentuk fleksibel. Program ini hanya mengizinkan ligan untuk menyesuaikan posisi/berubah konformasi sedangkan protein tidak. Hal ini tidak sesuai dengan keadaan asli pada manusia dimana baik protein dan ligan bersifat fleksibel sehingga keduanya dapat menyesuaikan bentuk untuk memperoleh posisi yang sesuai.

\section{KESIMPULAN}

Scopoletin memiliki skor docking yang lebih rendah dibandingkan standar yang digunakan.Visualisasi hasil docking scopoletin memperlihatkan scopoletin mampu membentuk ikatan dengan kedua tempat ikatan Tf pada RTf-2. Oleh karena itu, scopoletin diprediksi sebagai salah satu agonis RTf-2 secara molecular docking.

Penelitian lanjutan berupa uji in vitro sebaiknya dilakukan untuk mengetahui apakah terjadi kompetisi antara holo- Tf dengan senyawa scopoletin pada RTf- 2 .

\section{UCAPAN TERIMAKASIH}

Terimakasih kepada Yuliana Heri Suselo, dr., M.Sc., Amelya Augusthina Ayu Sari, dr., Yoga Mulia Pratama, S.Ked, dan Linda Erlina, S.Farm yang telah membantu dalam berjalannya penelitian ini. 


\section{DAFTAR PUSTAKA}

1. Bregman DB, Morris D, Koch TA, He A, Goodnough LT. Hepcidin levels predict nonresponsiveness to oral iron therapy in patients with iron deficiency anemia. AJH 2013; 88(2): 97-101.

2. Johnson-Wimbley TD, Graham DY. Diagnosis and management of iron deficiency anemia $i$ the 21st century. Therap Adv Gastroenterol 2011; 4(3): 177-184.

3. Pietrangelo A. Review Hepcidin in human iron disorders: Therapeutic implications. J Hepatol 2011; 54(1): 173181.

4. Poli M, Asperti M, Ruzzenenti P, Regoni M, Arosio P. Hepcidin antagonists for potential treatments of disorders with hepcidin excess. Front Pharmacol 2014; 5: 1-13.

5. Fleming MD. The regulation of hepcidin and its effects on systemic and cellular iron metabolism. ASH 2008; 2008(1): 151-158.

6. Hernani. Pengembangan biofarmaka sebagai obat herbal untuk kesehatan. B Pascapanen 2011; 7(1): 20- 29.

7. Menkes RI 2013. Lampiran Peraturan Menteri Kesehatan Republik Indonesia Nomor 87 tahun 2013 tentang Peta Jalan Pengembangan Bahan Baku Obat. Jakarta: Menteri Kesehatan Republik Indonesia.

8. Yanuar A. Penambatan Molekular: Praktek dan Aplikasi pada Virtual Screening. Depok: Fakultas Farmasi Universitas Indonesia; 2012.

9. Lipinski CA, Lombardo F, Dorminy BW, Feeney PJ. Experimental and computational approaches to estimate solubility and permeability in drug discovery and development settings. Adv Drug Delivery Rev 2001; 46(1-3): 3-26.

10. Yamamura T, Sakajiri T. The Computational Structure Model of The Differic Transferrin- Transferrin Receptor 2 Complex Involved in Body's Iron Homeostasis [Online]. 2011 [cited
$2015 \quad$ Aug 10]. Diunduh dari;URL:http://www2.kenes.com/apccn/ scientific/Documents/Poster/1152.

11. Bordoli L. Introduction to 3D-Structure Visualization and Homology Modeling using the Swiss-Model Workspace [Online]. 2009 [cited 2015 Dec 3]. Diunduh dari; URL:http://edu.isbsib.ch/pluginfile. php/735/course/section/1235/Introductio n-SMW partIV-ho.pdf.

12. Yuwono T. Biologi Molekular. Jakarta: Erlangga; 2008.

13. Hart DJ, Hadad CM, Craine LE, Hart H. Kimia Organik. Jakarta: Erlangga; 2003.

14. Merz KM, Ringe D, Reynolds CH. Drug design: Structure-and ligand-based approaches. New York: Cambridge University Press; 2010.

15. Lipinski CA. Lead- and drug-like compounds: the rule-of-five revolution. Drug Discov Today Technol 2004; 1(4): 337-341.

16. Hidayat T, Wahyuni ES, Karyono SS. Pengaruh ekstrak buah mengkudu (Morinda citrifolia) terhadap aorta terpisah marmut (Cavia porcellus) tanpa endotel. JKB [serial online] 2005 [cited 2015 Nov 25] Diunduh dari:URL:http://www.jkb.ub.ac.id/index. php/jkb/article/viewFile/244/234

17. Li C, Han X, Zhang H, Wu J, Li B. Effect of scopoletin on apoptosis and cell cycle arrest in human prostate cancer cells in vitro. Trop J Pharm Res 2015; 14(4): 611-617.

18. Malik A, Kushnoor A, Saini V, Singhal $\mathrm{S}$, Kumar S, Yadav YC. In vitro antioxidant properties of Scopoletin. J Chem Pharm Res 2011; 3(3): 659-665.

19. Cheng AS, Cheng YH, Chang TL. Scopoletin attenuates allergy by inhibiting Th2 cytokines production in EL-4 T cells. Food Fuct 2012; 3(8): 886890.

20. Pan R, Gao X, Lu D, Xu X, Xia Y, Dai Y. Prevention of FGF-2-induced angiogenesis by scopoletin, a coumarin compound isolated from Erycibe 
Paramanindita et al, Potensi Scopoletin sebagai Agonis Reseptor Transferin 2 untuk Pengembangan Terapi Anemia Defisiensi Besi

obtusifolia Benth, and its mechanism of action. Int Immunopharmacol 2011; 11(12): 2007-2016. 